ECONOMIC THEMES (2019) 57(2): 165-179

sciendo

DOI 10.2478/ethemes-2019-0010

\title{
OVERCOMING THE EFFECTS OF RESTRICTIVE FISCAL POLICY: THE CASE OF ARGENTINA AND SERBIA
}

\author{
Miloš Todorović \\ University of Niš, Faculty of Economics, Serbia \\ $\bowtie$ milos.todorovic@eknfak.ni.ac.rs \\ Ivan Marković \\ University of Niš, Faculty of Economics, Serbia \\ $\bowtie$ ivan.markovic@eknfak.ni.ac.rs
}

Dijana Grahovac

University of Business Studies, Banja Luka, Bosnia and Herzegovina

$\triangle$ jonidg11@yahoo.com

UDC

336.02

$(82+497.11)$

Review

paper

Received:

29.01.2019

Accepted:

25.04.2019

\begin{abstract}
The paper analyses one of the most important economic issues relevant to most countries. The issue involves how to as painless as possible overcome the problems of high budget deficits and excessive accumulated public debt. Argentina and Serbia are used as an example. Argentina implemented rigorous saving measures in 2002 and Serbia began to implement restrictive budgetary measures in 2014. The effects of such a policy can be designed for the future. Results indicate that the key to Argentina's success lies in the transition to a floating exchange rate and the high level of correlation between the growth of the foreign exchange rate and growth in exports. When comparing strict fiscal policy in Argentina and Serbia, it should be emphasised that the measures in Serbia are far less stringent than those that were established in Argentina. But it also means that the effect of reducing budget expenditures should have less of an impact on GDP reduction than in the case of Argentina.
\end{abstract}

Keywords: fiscal policy, monetary stability, debt, deflation.

JEL classification: F34, F42 


\section{Introduction}

How to achieve a satisfactory economic growth rate with inevitable restrictive fiscal policy measures, reducing budget deficit and public debt, is the burning issue of contemporary economic science. Argentina is trying to overcome this problem by encouraging exports and foreign direct investment. The positive effects of this approach significantly reduce the global economic crisis that slowed foreign trade and capital transfer. Argentina declared bankruptcy in December 2001 after a disastrous economic and political crisis. It had one of the biggest external debt defaults in history. That left the world speechless. The official negotiation strategy for the external debt has been "repay-as-much-as-possible". Borrowing funds from creditors puts a country in a subordinate position and gets it under pressure of becoming indebted (Toussaint and Millet, 2010). In the last three decades, countries removed the barriers for capital movement and granted tax exemptions for many sectors involving foreign capital. This deregulation of external trade provides another source of national income through foreign investment and promoting export sales (Harvey, 2005).

The Republic of Serbia has a budget deficit that is far from the limit specified by the European Monetary Union, the public debt being above the legal limit determined by the Government, the external debt on the verge of overindebtedness, relatively high domestic debt of the public and private sector. All debts mentioned separately do not represent a big problem but observed unified become a burden for the weak economy of Serbia. This can lead to a default of payment and bankruptcy (Jankovic, 2015).

When comparing strict fiscal policy in Argentina and Serbia, it should be emphasised that the measures in Serbia are far less stringent than those that were established in Argentina. But it also means that the effect of reducing budget expenditures should have less of an impact on GDP reduction than in the Argentinian case. Fiscal expansion is usually followed by deficit of the current account balance and an appreciation of currency. This is called the twin deficit hypothesis (Obadic, Globan and Nadoveza, 2014).

The key issue of the paper is why restrictive budgetary policy measures taken by Argentina are not so effective and why cannot we expect satisfactory effects from similar measures in the Republic of Serbia? The first part of the answer is related to external factors, which entails a global economic crisis that slows down international trade and foreign direct investment. Even more important is the internal factor that distinguishes Argentina from Serbia and consists in capacity and reagibility of economy on export incentives.

Serbia is trying to implement measures that have given effects in Argentina since 2014, before the outbreak of the global economic crisis gave results. But the effects of such measures may not be similar to Argentinian. Argentina's measures 
in 2002 were implemented with a stable environment (in the pre-crisis period), while the measures in Serbia correspond to the post-crisis period, when the world economy still suffers from the consequences of years of stagnation and recession. Dimensions in Serbia are far less restrictive than Argentinian. But, the key measure of success for lack of restrictive budgetary policy in Serbia is far less flexibility and export capacity of the economy, especially poor responsiveness of government stimulus measures. This is what proves the analysis conducted in the paper.

\section{Literature review}

Currency crises occur when governments try to pursue ambitious macroeconomic policies and that inevitably leads to abandonment of a fixed exchange rate. Mundell (1963) examined the impact of economic policy under different exchange rate regime in the process of macroeconomic stabilization. Krugman (1979) said that when perfectly predicting a transition from one exchange rate regime to another, usually from fixed to a floating one in the moment of change there was a possibility of speculative attack. Private participant try to buy all the foreign currency reserves whose parity the Central Bank is bound to defend.

Sturzenegger and Zettelmeyer have conducted an analysis of debt factors crises in seven emerging market countries between 1998 and 2005: Argentina, Ecuador, Uruguay, Russia, Moldova, Ukraine and Pakistan. For driving sovereign currency, balance of payments and stopping crisis global factors can play an important role. Some of the factors which can cause crisis are degradation of the terms of trade, change of world interest rates, and global commodity prices. Jorda, Schularick and Taylor said that low interest rates were a suitable ground for the global financial crisis to appear. Some studies show that recent crisis and the global imbalances of the 2000s are tightly related (Obstfeld and Rogoff, 2009; Obstfeld, 2012).

Many economic theorists have been concerned with the relationship between exchange rate depreciation and increased exports. Short run degradation and long run melioration after the depreciation of currency looks like the letter "J" and it is called the J-curve phenomenon. It was first mentioned by Magee (1973).

Brander and Spencer proved that domestic economy could profit from export subsidies. Homeland economy can help its companies to grab a bigger share of profit from international market by using export subsidies. The presence of J-curve phenomenon and its long and short-term effects are tested by a large number of empirical studies. Japanese results prove the theory for both the short and the longrun effects of currency depreciation on trade balance and the J-curve effect.

Gupta-Kapoor and Ramakrishnan (1999) used data from 1975 to 1996, and noted that depreciation led to trade balance improvement. They used the Johansen procedure and indicated a relation between trade balance, exchange rate, and foreign and domestic GDP. 
There is a wide range of theorists who deny the link between the exchange rate and increasing exports, considering the effects of other market factors, but in the Argentinian case it expressed very strong direct-correlations. Economic theorists have different views on the reasons of the economic crisis in Argentina.

The causes of the Argentinian crisis have differentiated over the past years according to the available literature.

Mussa (2002) blames pale fiscal tightening in the middle of the decade as then the economy grew over 7 percent annually, which is somewhat related to overvalued potential output growth in Argentina during the 1990`s.

Hausman and Velasco (2002) point to the steep downturn of 1998 as the cause of the crisis. That led to declining future export growth expectations, which caused higher risk premia and capital inflow deterioration. Next consequence was lowering of domestic investment, smaller output and worsening of credit rank and the ability to borrow.

Different point of view indicated the exchange rate regime as the main cause of the crisis. Feldstein (2002) noted that improving competitiveness by conventional currency devaluation was made impossible by the fixed exchange rate. Another thing that aborted the effect of devaluation was the union's resistance to lowering the wages, which prevented the fall of production costs.

Roubini (2001) and De la Torre (2002) claimed that the adjustment of a real exchange rate and the balance sheet effects were not defended by convertibility. The repayment capacities of debtors whose inflows come from non-tradable sector are diminished as convertibility could lead to deflation and unemployment as the adjustment of balance sheet.

\section{Research methodology}

In the paper, the Pearson correlation coefficient and coefficient of determination are used. In statistics, a measure of the degree of linear dependence between two variables, $\mathrm{x}$ and $\mathrm{y}$ is called the Pearson correlation coefficient. It is widely used in researches. The mathematical formula for computing $r$ is:

$r=\frac{\sum_{i=1}^{N} \frac{\left(x_{i}-\bar{x}\right)}{\delta_{x}} \cdot \frac{\left(y_{i}-\bar{y}\right)}{\delta_{y}}}{N}=\frac{\frac{1}{\delta_{x} \delta_{y}} \sum_{i=1}^{N}\left(x_{i}-\bar{x}\right)\left(y_{i}-\bar{y}\right)}{N}$ 


$$
\begin{aligned}
& r=\frac{\sum_{i=1}^{N}\left(x_{i}-\bar{x}\right)\left(y_{i}-\bar{y}\right)}{N \delta_{x} \delta_{y}}=\frac{\sum_{i=1}^{N}\left(x_{i} y_{i}-\bar{x} y_{i}-\bar{y} x_{i}+\overline{x y}\right)}{N \sqrt{\frac{\sum_{i=1}^{N}\left(x_{i}-\bar{x}\right)^{2}}{N} \sqrt{\frac{\sum_{l=1}^{N}\left(y_{i}-\bar{y}\right)^{2}}{N}}}} \\
& r=\frac{\sum_{i=1}^{N} x_{i} y_{i}-N \overline{x y}}{\sqrt{\sum_{i=1}^{N} x_{i}^{2}-N \bar{x}^{2}} \sqrt{\sum_{i=1}^{N} y_{i}^{2}-N \bar{y}^{2}}}
\end{aligned}
$$

In the formulas $\mathrm{n}$ represents the number of pairs of data. The $\mathrm{r}$ value can go from $-1<\mathrm{r}<+1$. If $\mathrm{r}$ equals exactly 1 it shows a perfect positive correlation. An $\mathrm{r}$ value of exactly -1 indicates a perfect negative fit. If it is close to 0 it indicates a random, nonlinear relationship between the two variables. Other model used coefficient of determination, which, in statistics, denoted $\mathrm{R}^{2}$ or $\mathrm{r}^{2}$ and pronounced $\mathrm{R}$ squared, indicates how well data fit a statistical model. It provides a measure of how well observed outcomes are replicated by the model, as the proportion of total variation of outcomes explained by the model (Glantz and Slinker, 1990, 187). The mentioned statistical methods are chosen in accordance with the aim of determining the degree of intensity of the correlation between observed variables (correlation coefficient) and determining the percentage ratio of the variance of the response are explained by the regression, and which percentage ratio of the variance are left over in the residuals (coefficient of determination).

\section{Comparative analysis of restrictive budgetary policy in the cases of Argentina and Serbia}

\subsection{The case of Argentina}

The turbulent economic history of Argentina in the last two decades of the 20th century is characterised by postponing and rambling in solving the pressing economic issues and finally in 2001 culminated in the greatest crisis that Argentina has ever had.

In the 1980s, Argentina was burdened by a high rate of inflation (over 200\%). With an already large external debt, its internal indebtedness also increased as the country assumed the debts of companies that were going bankrupt. As a way to provide monetary stability for the Argentinean Peso, the Central Bank of Argentina, following the advice of the IMF, introduced a new currency board and 
fixed its exchange rate to the US Dollar. As a result of these actions in 1993 inflation was "only" 7.4\%. However, a new currency shock quickly followed when the Brazilian Real was devalued by $40 \%$ impacting on its exchange rate with the Argentinean Peso. This devaluation lead to a rapid deterioration in the Argentinean balance of payments and increased foreign indebtedness. This started a flight of capital from the country and along with negative growth of $3.4 \%$ and decreased investments in 1999 resulting in deflation of $1.8 \%$ which led to a drastic fall in the standard of living for the general population. The crisis reached its head in 20012002. Table 1 shows that in 2002, GDP fell $10.9 \%$, inflation was at $41 \%$ and the unemployment rate was $21.5 \%$ while the rate of foreign indebtedness continued to grow (as a percentage of GDP).

Table 1. Basic macroeconomic indicators of Argentina (2002-2005)

\begin{tabular}{|c|c|c|c|c|}
\hline & 2002 & 2003 & 2004 & 2005 \\
\hline GDP (mil. USD) & 123607 & 156988 & 183295 & 222907 \\
\hline GDP (mil. Pezos) & 383182 & 470964 & 531556 & 646430 \\
\hline Growth (\%) & -10.9 & 8.7 & 9.0 & 9.2 \\
\hline Inflation $(\%)$ & 41.0 & 3.7 & 6.1 & 12.3 \\
\hline External debt (\% GDP) & 117.83 & 102.63 & 89.97 & 57.17 \\
\hline External debt (mil. USD) & 145644 & 161120 & 164915 & 127451 \\
\hline Unemployment rate $(\%)$ & 21.5 & 15.6 & 14.8 & 10.6 \\
\hline
\end{tabular}

The Graph 1 shows a drastic drop in consumption in the period 1999 - 2000, but with a significant reduction in budgetary spending during and after this period.

Graph 1. Consumption in Argentina in the period 1998-2005
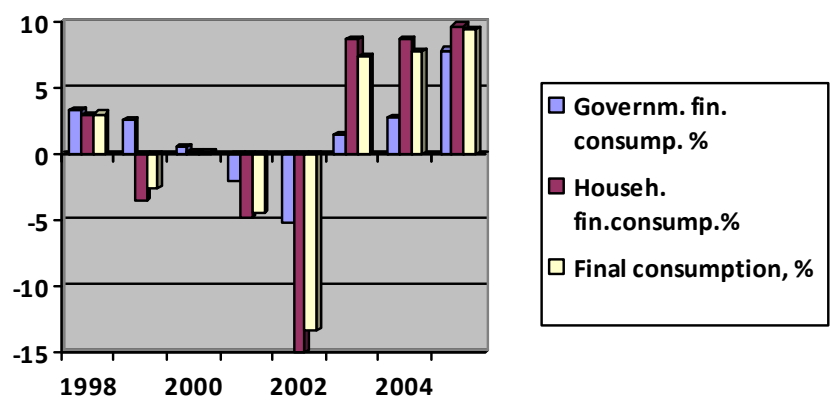

A large number of authors agree that the austerity measures taken by the euro zone countries practically contributed in deepening the crisis and slowing down the growth. In fact, they have not achieved. 
It is generally accepted that in times of crisis and economic downturn there is a significant inflow of investments. However, in times of depression with a fixed exchange rate, a large external debt, large budget deficits, open markets and reduced spending, it is unlikely that there will be any influx of investment in such economic circumstances. Consequently, this resulted in high unemployment and the total collapse of the Argentinean economy. It was only with the reintroduction of a floating exchange rate, a significant devaluation of the Peso, resulting in the reduction in the value of products and labour and two long years of economic pain and suffering that Argentina managed to emerge from the crisis.

Defending a fixed exchange rate from speculative attacks was impossible for the Argentinean Central Bank. It was forced to introduce a floating exchange rate where the Peso was allowed to float freely in relation to other currencies. It was have a positive effect as soon as 2003 when there was a positive growth rate of more than $1 \%$ and by 2004 tight monetary policy brought down inflation to $6.1 \%$. (Table 1). Table 2 reveals that a high correlation coefficient is evident, which indicates a positive correlation between the exchange rate as an independent variable, and its significant impact on the exports of Argentina, as the dependent variable. Multiplier effects of exports to GDP growth is reflected in a fall in the unemployment rate after only a few years to just over $10 \%$ (the unemployment rate in 2004 was $14.8 \%$ ). It is obvious that the fixed exchange rate regime and currency board completely discouraged exports.

The coefficient of determination in Table 2 expresses the structure of analysed sample which is explained by the correlation coefficient. And this ratio is also high and provides an explanation that the regression explains $90.1 \%$ of the variance of the response, while $9.9 \%$ of this variance is left over in the residuals (R Square). Considering that, the sample size is not large enough, for relevance of obtaining statistical results, in the paper is used Adjusted R Square. It indicates the specific overvaluation R squares. However, this ratio is extremely high and indicates that 88.5 of the variance of the response can be explained by the regression, and $11.5 \%$ of this variance is left over in the residuals. An F-test is used for testing the Rsquare change, also known as the F-change. If there is a significant F-change it shows that the predictions were drastically improved by the added variables in the last step (which is the case here). Significant F Change is considerably less than 0.05 and point out that those combinations of variables are statistically significant. All of used methods show that the key to Argentina's success lies in the transition to a floating exchange rate and the high level of correlation between the growth of the foreign exchange rate and growth in exports. 
Table 2. Correlation between exchange rate and export

\begin{tabular}{|c|c|c|c|c|c|c|c||}
\hline & & & & \multicolumn{4}{|c|}{ Change Statistics } \\
\cline { 5 - 8 } Model & $\mathrm{R}$ & R Square & $\begin{array}{c}\text { Adjusted R } \\
\text { Square }\end{array}$ & $\begin{array}{l}\text { R Square } \\
\text { Change }\end{array}$ & $\begin{array}{c}\mathrm{F} \\
\text { Change }\end{array}$ & df1 & $\begin{array}{c}\text { Sig. F } \\
\text { Change }\end{array}$ \\
\hline 1 &, $949^{\mathrm{a}}$ &, 901 &, 885 &, 901 & 54,863 & 1 &, 000 \\
\hline
\end{tabular}

Source: calculation of authors

The most obvious is impact of changes in the exchange rate regime through a consideration of the impact on trade to \% of GDP (Table 3), with almost perfect elasticity. The coefficients of R Square Adjusted R Square support that conclusion.

Table 3. Correlation between exchange rate and trade-\% of GDP

\begin{tabular}{|c|c|c|c|}
\hline Model & & R Square & Adjusted R Square \\
\hline 1 & $990^{\mathrm{a}}$ & 980 & 977 \\
\hline
\end{tabular}

Predictors: (Constant), Exchange rate Source: calculation of authors based on of data: World Bank - Indicators

The effect of the depreciation of pesos manifested through the impact of export's increasing in GDP, which shows the export ratio in Table 4. The effect of depreciation is seen in 2002 with a radical increase in the export coefficient of $2,620 \%$.

Table 4. The coefficient of exports of Argentina

\begin{tabular}{||l|c|c|c|c|c|c|c||}
\hline 1998 & 1999 & 2000 & 2001 & 2002 & 2003 & 2004 & 2005 \\
\hline 0.07 & 0.07 & 0.08 & 0.08 & 0.21 & 0.19 & 0.19 & 0.18 \\
\hline
\end{tabular}

Source: calculation of authors based on of data: World Bank - Indicators

It is clear that a restrictive fiscal policy of Argentina in 2001 and 2002 brought poverty, but the government consolidated the budget and individual consumption within realistic limits. Furthermore, the introduction of a floating exchange rate delivered good results such as the creation of an environment favourable to investment with high export linked to the growth of exchange rate as the key factor. If we are looking for an answer to the question of the high price elasticity of domestic supply of exports, the answer will probably lie in the modest purchasing power of the local population and by much closer exchange rates to the equilibrium. Finally, up to the outbreak of the global financial crisis, the world economy and world trade had a stable growth rate, which was beneficial to Argentinean exports. 


\subsection{The case of Serbia}

In the 1990s, Serbia was excluded from international economic markets by the United Nations embargo. After opening itself to the world, it maintained a fixed exchange rate for a few months until January 2001 when the national currency (the Dinar) was left to float freely in the foreign exchange markets. There was a huge growth of foreign trade following years of its absence but it was very much limited to imports. This led to the accumulation of foreign debt that exceeded $80 \%$ of GDP. The deficit was partially covered by an inflow of foreign investments to the process of privatization that was underway. However, since 2000 the Central Bank of Serbia has managed to keep monetary stability with low two-digit or single-digit inflation rates. That resulted also in a relative stable floating exchange rate.

In 2009 and 2012, Serbia recorded negative growth rates as a result of the global financial crisis, which, together with a very high unemployment rate (consistently over $20 \%$ ) made the economic situation very serious (Table 5). In 2014 a negative growth existed, which is a result of the floods, which have caused considerable material damage and completely paralysed, among other things, economic flows. In 2015, the recovery was followed by positive growth, but with increasing external debt.

Table 5. Basic macroeconomic indicators of Serbia

\begin{tabular}{|l|c|c|c|c|c|c|c|c|c|}
\hline \hline & 2007 & 2008 & 2009 & 2010 & 2011 & 2012 & 2013 & 2014 & 2015 \\
\hline GDP, bill LCU & 2335 & 2744 & 2880 & 3067 & 3407 & 3584 & 3876 & 3908 & 3973 \\
\hline Growth rate (\%) & 5,9 & 5,4 & $-3,1$ & 0,6 & 1,4 & $-1,0$ & 2,6 & -1.8 & 0.8 \\
\hline Consumer price \% & 11,0 & 5,6 & 6,6 & 10,3 & 7,0 & 12,2 & 2,2 & 1.7 & 1.5 \\
\hline Unemployment rate (\%) & 18,1 & 18,6 & 16,1 & 19,2 & 23,0 & 23,9 & 22,1 & 19,4 & 17,9 \\
\hline External debt, \% GDP & - & 70,2 & 79,3 & 87,1 & 78,7 & 80,9 & 75,1 & 77,3 & 80,3 \\
\hline Reference interest rate (\%) & 10,0 & 17,75 & 9,5 & 11,5 & 9,7 & 11,25 & 9,5 & 8,0 & 6,1 \\
\hline
\end{tabular}

Source of data: National Bank of Serbia

Another problem was a constantly growing budget deficit and the public debt exceeded $75 \%$ of GDP in 2014. Facing serious problems, the Government of Serbia finally decided to adopt the unpopular measure of restrictive budgetary policies in 2014. As Serbia was a regional leader in terms of pension expenditures and public sector salaries employees in terms of percentage of GDP, the first measure was their linear reduction by $10 \%$. In addition, savings were planned by every ministry along with a decrease in subsidies for industry and agriculture. The total planned reduction in expenditure was 3.5\% (Table 6). In 2014, personal income decrease and savings had the effect but not for long because of flood influence. 
Table 6. Budget of Serbia

\begin{tabular}{|l|c|c|c|c|c|c||}
\hline & 2010 & 2011 & 2012 & 2013 & 2014 & 2015 \\
\hline Budget, bill LCU & 762,9 & 850,1 & 874,5 & 1087,6 & 1121,9 & 1083 \\
\hline \hline
\end{tabular}

Source of data: National Bank of Serbia

The essence of these governmental measures is the decomposition of budget expenditure in favour of investment, at the expense of budget and personal spending (Table 7). Current public spending should be reduced more than the fiscal deficit. In 2014, there was a reduction in the Government's spending by $5 \%$, and a reduction private consumption by $0.4 \%$, but there was a reduction in investments, also, which was mostly result of floods impact. According to the Serbian Government's projection - Government's spending should have been reduced by $4.4 \%$ and $3.6 \%$ in 2015 and 2016 , respectively. But, it did not happen, because government spending reduced only $1.9 \%$ in 2015 . Some analysts suggest that Serbia will achieve stable growth rates only when exports form more than $50 \%$ of GDP. As the Serbian foreign exchange market is very shallow, such forecasts are achievable. The establishment of just one company (e.g. the steel mill in Smederevo, which is already in the process of privatization) would increase exports by more than $20 \%$ and GDP by more than $1 \%$.

Table 7. Participation of consumption in budget

\begin{tabular}{|l|c|c|c|c|c|c|c|c||}
\hline & 2007 & 2008 & 2009 & 2010 & 2011 & 2012 & 2013 & 2014 \\
\hline Final consumption, \% of GDP & 95,2 & 96,8 & 99,6 & 99,9 & 96,3 & 96,9 & 93,2 & 94,4 \\
\hline $\begin{array}{l}\text { Government final consumption, } \\
\% \text { of GDP }\end{array}$ & 20,5 & 20,0 & 19,9 & 19,7 & 19,3 & 19,9 & 19,1 & 18,1 \\
\hline $\begin{array}{l}\text { Household final consumption, } \\
\% \text { of GDP }\end{array}$ & 74,7 & 76,8 & 79,7 & 80,2 & 77,0 & 77,0 & 75,1 & 74,8 \\
\hline Gross investments & 24,3 & 23,8 & 18,8 & 17,8 & 18,5 & 21,4 & 20,5 & 16,7 \\
\hline
\end{tabular}

Source of data: National bank of Serbia, World Bank

All projections would finally result in the growth of GDP and the settlement of monetary and financial situation in the country. Ensuring monetary stability would be implemented by the Central Bank of Serbia, as it is now. It should be noted that the monetary authorities can have a relatively modest effect in reducing interest rates, which would boost investment. So far, commercial banks have shown very little willingness to lower their profits even in the case of the sharp fall in the rate of inflation. Experience suggests that changes in the financial markets so far (including the reduction of the rate of inflation) have mainly affected the maintenance of nominal interest rates in the market and increased profits of banks. 
When it comes to reducing the budget and personal spending the basic question is whether the most vulnerable sections of society will withstand these measures, or whether the government will see through their unpopular application. It is obvious that the abandonment of the already announced introduction of salary grades in all institutions financed from the budget is a step in the wrong direction from the planned trough austerity measures. It also means a selective approach in implementing austerity measures is being adopted, as salary levels would not directly endanger the poorest in society.

Problematic issues are the projections for investments. The fulfilment of the previous conditions (redistribution of budget spending) is a necessary, but insufficient condition for achieving the desired goal. Domestic investment should be properly directed, and foreign investments are highly questionable. Experience tells us that very often ambitious and well-designed projects fail in the implementation phase and that the plan of FDI inflow is often several times higher than those finally realised.

The most problematic parameter is the projection of exports. On one hand, the problem is the state of export markets (primarily the European Union and Russia). Very low growth rates in the EU does not promise a growth in demand for imports, although the announced injection of more than one billion Euros into the euro zone over the next eighteen months provides some hope. Perhaps an even bigger problem is the very low price-elasticity of domestic export supply, i.e. very little correlation between price movements and Serbian exports. It was this parameter that gave momentum to Argentina's economy. Therefore, one can only hope that this parameter will be fulfilled with the influx of foreign investment. In other words, in the case of Serbia, the prerequisites for the Marshall-Lerner condition are not met because it is highly dependent on import without the possibility of diverting demand towards domestic producers and because the structure of export products is mainly dominated by lower levels of production for which the demand is very unstable. That is why it cannot count on lowering the value of the national currency as a measure to incentivise exports because it will not meet that goal and it will only put pressure on prices in the hypersensitive domestic market.

From Table 8 a high correlation coefficient is evident, which indicates a positive correlation between the exchange rate and its significant impact on the exports of Serbia. The coefficient of determination provides an explanation that 81 $\%$ of the variance of the response is explained by the regression, and $19 \%$ of this variance is left over in the residuals (R Square). Adjusted R Square indicates that this ratio is higher and points out that the regression explains $77.2 \%$ of the variance of the response, while $22.8 \%$ of this variance is left over in the residuals. 
Table 8. Correlation between exchange rate and export

\begin{tabular}{||l|l|l|l||}
\hline Model & R & R Square & Adjusted R Square \\
\hline &, 900 &, 810 &, 772 \\
\hline
\end{tabular}

Predictors: (Constant), Exchange rate 1EUR

Source: calculation of authors based on of data: World Bank - Indicators

Comparing the results in Table 9 with the previously mentioned, it can be concluded that exports grew faster than imports, as the coefficient of influence of the exchange rate on exports is significantly higher than the coefficient of the exchange rate impact on overall trade, as \% of GDP. This result is certainly encouraging for the monetary authorities in Serbia to continue with the same policy.

Table 9. Correlation between exchange rate and trade- \% of GDP

\begin{tabular}{|c|c|c|c|c|}
\hline Model & \multicolumn{2}{|c|}{$\mathrm{R}$} & R Square & Adjusted R Square \\
\hline 1 & &, $701^{\mathrm{a}}$ &, 492 &, 407 \\
\hline
\end{tabular}

Predictors: (Constant), Exchange rate Source: calculation of authors based on of data: World Bank - Indicators

Coefficient of Serbian exports in the period 2007-2015 (Table 10) had a growth trend and the ratio of 2015/2007 was 1.74 , what indicates a good use of the potential of the export sector. But certain danger, as already mentioned in the paper, is the shallowness of the foreign exchange market through a small number of exporting companies, with a large share. Therefore, the main goal for the economic authorities in Serbia is to focus efforts on expanding this market and maintaining stability.

Table 10. The coefficient of exports of Serbia

\begin{tabular}{|c|c|c|c|c|c|c|c|c|}
\hline 2007 & 2008 & 2009 & 2010 & 2011 & 2012 & 2013 & 2014 & 2015 \\
\hline 0,27 & 0,28 & 0,26 & 0,32 & 0,33 & 0,36 & 0,40 & 0,43 & 0,47 \\
\hline
\end{tabular}

Source: calculation of authors

The Serbian Government has another important task in the process of implementation of restrictive budgetary policies. It is the prevention of unmanaged outflow of budget funds through various legal and illegal channels. Dealing with the problem of corruption could enable much greater savings than the official measures taken. In this work much greater results are achieved through the control of the process than creating a budget. 


\section{Conclusion}

Restrictive fiscal policies directly affect the reduction of gross domestic product. The question is how we would then be able to overcome deflation and debt by fiscal policies. If we rephrase the question, it would sound: how to increase investment and economic activity without increasing indebtedness? One of the solutions might be foreign direct investment. It not only increases employment and gross domestic product, but also introduces the export market and increases foreign exchange inflows. The success of the implementation of restrictive budgetary policy measures depends mainly on the shock absorbers that reduce their impact on GDP. Central bank's role is not crucial in this process because it primarily ensures monetary stability and, depending on the efficiency of the government's monetary policy, makes it easier to accomplish these goals. The effect of the restrictive budgetary policy will depend more on the expertise of the government, its perseverance in achieving its objectives and self-control wining over selfcenteredness and greed. Good governments think about future generations, not about next elections. The key to Argentina's success lies in transition to a floating exchange rate and high level of correlation between growth of foreign exchange rate and growth in exports. When comparing strict fiscal policy in Argentina and Serbia it should be emphasised that the measures in Serbia are far less stringent than those that were established in Argentina. But it also means that the effect of reducing budget expenditures should have less of an impact on GDP reduction than in case of Argentina. Argentina had three important factors on its side: high correlation of exports and foreign exchange rate, positive economic development in the countries' foreign trade partners and it managed to persevere the implementation of its austerity programme. These very same elements would be major obstacles in the implementation of a successful restrictive budgetary policy by the Serbian government. In other words, Serbia is faced with the challenging issue of how to alleviate the negative impact of restrictive budgetary policy on GDP.

\section{References}

Ariño, A., de la Torre, J. Lorenzoni. G. 2002. Process issues in international alliance management: A debate on the evolution of collaboration, in Managing Transnational Firms: Resources, Market Entry and Strategic Alliances, M.A. Hitt and J.L.C. Cheng Eds. Advances in International Management, 14, pp. 173-219.

Cantamutto, F., Ozarow, D. 2015. Argentina's debt affair: far beyond vulture funds. World Economics Association (WEA) Conferences, No. 1 2015. Ideas towards a new international financial architecture", 15th May - 20th July, 2015

Feldstein, M. 2002. Lessons from Argentina. mimeo Harvard University, pp.8-14

Glantz, S., Slinker, B. 1990. Primer of Applied Regression and Analysis of Variance. McGraw-Hill. 
Gupta-Kapoor, A., Ramakrishnan, U. 1999. Is There a J-curve? A New Estimation for Japan. International Economic Journal, 13(4): 71-79.

Harvey, D. 2005. A Brief History of Neoliberalism. New York: Oxford University Press, pp. 66.

Hausmann, R., Velasco, A. 2002. The Argentine collapse: hard money's soft underbelly, Harvard University.

Brander, J., Spencer, B. 1985. Export subsidies and international market share rivalry. Journal of International Economics 18, pp.83-100. North-Holland.

Jankovic, N. 2015. A twin deficit - the issue of the Serbian economy. Economic Horizons. May - August 2015, Volume 17, Number 2, p. 107 - 122.

Jordà, O., Schularick, M., Taylor, A. 2011. Financial Crises, Credit Booms, and External Imbalances: 140 Years of Lessons. National Bureau of Economic Research, Working Paper No. 16567, pp. 1-41.

Krugman, P. 1979. A model of balance of payments crises. Journal of Money, Credit, and Banking 11: 311-325

Magee, P.S. 1973. Currency Contracts, Pass-through, and Devaluation. Brookings Papers on Economic Activity, 1:1973, pp.303-325.

Mundell, R.A. 1963. Capital Mobility and Stabilization Policy under Fixed and Flexible Exchange Rates. Canadian Journal of Economics.

Mussa, M. 2002. Argentina and the Fund: from Triumph to Tragedy. Policy analyses in international economics. Institute for International Economics August 2002.

Obadic, A., Globan, T., Nadoveza, O. 2014. Twin Deficit Hypothesis in Countries with Indirect Tax-Oriented Systems. Panoeconomicus, (2217-2386). University of Novi Sad. Economists' Association of Vojvodina, Serbia. 653-667.

Obstfeld, M. 2012. Financial flows, financial crises, and global imbalances. Journal of International Money and Finance. Elsevier, vol. 31(3), pages 469-480.

Obstfeld, M., Rogoff, K. 2009. Global Imbalances and the Financial Crisis: Products of Common Causes. Asia Economic Policy Conference, Santa Barbara, CA, October 18-20. Federal Reserve Bank of San Francisco.

Pearson, K., 1895. Notes on regression and inheritance in the case of two parents. Proceedings of the Royal Society of London, 58: 240-242.

Roubini, N. 2001.Should Argentina dollarizes or float? The pros and cons of alternative exchange rate regimes and their implications for domestic and foreign debt restructuring. Working paper Stern Business School New York.

Sturzenegger, F., Zettelmeyer, J. 2007. Debt Defaults and Lessons from a Decade of Crises. Cambridge and London: MIT Press.

Toussaint, E., Millet, D. 2010. Debt, the IMF, and the World Bank: Sixty Questions, Sixty Answers. New York. Monthly Review Press, pp. 1-361. 


\section{PREVAZILAŽENJE EFEKATA RESTRIKTIVNE FISKALNE POLITIKE: SLUČAJ ARGENTINE I SRBIJE}

Apstrakt: U radu se analizira jedno od najvažnijih aktuelnih ekonomskih pitanja, za većinu zemalja, kako što "bezbolnije" upravljati problemom visokog budzetskog deficita i prekomernog akumuliranog duga. Kao primer, uzima se Argentina, koja je 2002. godine uvela rigorozne mere štednje, i Srbija, koja je u 2014. godini počela sprovoditi restriktivnu fiskalnu politiku. Efekti takve politike će biti vidljivi u budućem periodu. Rezultati rada pokazuju da je ključ argentinskog uspeha u prelasku sa fiksnog na fluktuirajući devizni kurs i visok nivo povezanosti između rasta deviznog kursa i rasta izvoza. Prilikom komaparacije čvrste fiskalne politike u Argentini i Srbiji trebalo bi naglasiti da su mere u Srbiji daleko manje stroge od onih koji su sprovođene u Argentini. Ali to takođe znači da će učinak smanjenja rashoda budzeta imati manje uticaja na smanjenje BDP-a nego u argentinskom slučaju.

Ključne reči: fiskalna politika, monetarna stabilnost, dug, deflacija

\section{Authors' biographies}

Miloš Todorović, $\mathrm{PhD}$ is a full professor at the Faculty of Economics, University of Niš. He is the author of a number of papers in the fields of International Economics and International Finance.

Ivan Marković, $\mathrm{PhD}$ is a full professor at the Faculty of Economics, University of Niš. The most recent area of research is the International Economy and the European Union.

Dijana Grahovac, $\mathrm{PhD}$ is an Associate Professor at the University of Business Studies in Banja Luka. She is the author of a number of papers in the field of economic integration, especially CEFTA. 